\title{
Prefatory Strategies in La Puce de Madame des-Roches: From the Salon to the Page
}

KENDALL B.

TARTE

Euvre collective des habitués de Madeleine et Catherine Des Roches lors des Grands Jours de Poitiers en 1579, l'anthologie La Puce de Madame des-Roches (1582) illustre la dynamique qui caractérise leur salon. Cet article propose une considération du livre imprimé, et en particulier des paratextes qui éclairent les stratégies textuelles et éditoriales. Ces paratextes - tels la page de titre, une préface du compilateur Jacques de Sourdrai, une deuxième préface qui remanie une lettre d'Estienne Pasquier - montrent la collaboration et l'échange qui ont contribué à la composition aussi bien qu'à la publication de La Puce.

$\mathrm{T}$

o a reader interested in the practices of the salon that Madeleine (ca. 1520-87) and Catherine (1542-87) Des Roches hosted in their Poitiers home, the published volume La Puce de Madame des-Roches (1582) offers a wealth of clues. The book records the poetic exchanges of their salon at a specific historical moment, that of the 1579 Grands Jours de Poitiers. ${ }^{1}$ The members of the Parlement de Paris who traveled to Poitiers for these special court sessions faced overcrowded courts and an unruly population; their professional duty was to reduce the judicial backlog in order to reinstate peace under the king's authority. The men found an antidote to the gravity of the legal proceedings in the cultivated conversation and witty banter of the provincial humanist salon. The current political situation offered an exceptional opportunity for literary publicity to the Des Roches, whose first volume of collected poems had been published the previous year in Paris. ${ }^{2}$ The initial visit of one eminent magistrate, Estienne Pasquier, his conversation with Catherine, and the ensuing poetic competition are perhaps the most famous results of the court sessions. Pasquier documented his version of those events for his friend Pierre Pithou in a letter that circulated in manuscript, was excerpted for the preface of La Puce, and appeared in Pasquier's published letters in 1586. He claims to have noticed on Catherine Des Roches' breast a 
flea, which he proposed they praise. The poems that each composed spurred a contest among the salon visitors, who wrote poems in several languages praising the insect. La Puce de Madame des-Roches collects those compositions and provides a glimpse into the salon culture. ${ }^{3}$

The present study investigates what the printed book reveals about the exchanges between those gathered at the Des Roches salon during the Grands Jours. It concentrates on the book as a material object, offering a systematic study of the paratextual features of La Puce de Madame des-Roches. Gérard Genette defines paratext as a strategic zone of both transition and transaction between text and hors-texte. ${ }^{4}$ Although Genette concentrates on modern texts, his formulation provides a useful point of departure for the discussion of sixteenth-century printed books. An examination of title pages, colophons, dedicatory epistles, prefaces to the reader, and royal privileges undoubtedly illuminates strategies of Renaissance authors and printers. In her study of the transition from manuscript to print in France, Cynthia J. Brown uses paratextual evidence to analyze the shifting roles of writers, printers, and publishers in late medieval France. ${ }^{5}$ Brown considers the social dynamics of book production, arguing that paratexts "shed light on the various producers of the text, by offering evidence of the simultaneous collaborative and competitive tensions involved in book production." 6 Similarly, in La Puce de Madame des-Roches, the paratextual materials expose the relationships of the participants in the salon community and of the various people responsible for the composition, compilation, and publication of the book. I argue here that the textual presentation of La Puce encourages a reading of the book as a collaborative production that favours community and exchange.

The opening pages of La Puce de Madame des-Roches present several layers of prefatory materials: a title page, two prose prefaces, and several epigrams. These works construct a series of authorial, authoritative figures. Each text reveals the role of one or more collaborators: the initiators of the poetic contest, the compiler of the collection, the publisher. Taken together, the introductory pieces mimic the atmosphere of the salon, which is both collaborative and competitive. They inscribe the social dynamics that produced the poems, showing the many forces responsible for the final product, the published book. In presenting the book to the reader, these texts also define the ideal audience and account for the text that will follow. An examination of the resulting portrait of the book brings to view the interests of authors and book producers.

These introductory paratexts also inform about the situation of women in salons in France in the late sixteenth century, and about Catherine Des Roches' role in particular. Recent analyses of La Puce de Madame des-Ro- 
ches concentrate on how the gender relationships play out in the poems, and specifically on Catherine Des Roches' textual strategies. ${ }^{7}$ Many of the men who contribute to the collection draw on the blason tradition in their detailed depictions of Catherine's imagined body. The paratextual apparatus of $L a$ Puce, however, directs attention away from the female body and toward the salon community, softening the gender tensions that are central to the book. The first pages of the anthology feature Catherine Des Roches as a learned, virtuous woman and as one of the initiators of the collection. This prefatory strategy creates an image of a book that is acceptable to a wide audience, one that includes women. The title page of the volume names directly only one of the participants in the flea contest: Catherine Des Roches herself. The full title of the anthology gives ownership of the insect to the woman, while claiming that joint authorship of the book's compositions belongs to several learned people: La Pvce de Madame des-Roches qvi est vn recveil de divers Poëmes Grecs, Latins \& François, composez par plvsievrs doctes personnages avx Grans Iours tenus à Poictiers l'An M.D.LXXIX. ${ }^{8}$ The two prose texts that follow the royal privilege and introduce the volume confirm Catherine Des Roches' presence. The compiler Jaques de Sourdrai's epistle to his patron, "A noble et vertvevx seignevr Ant. de la P. Gentilhomme Poicteuin," indicates that he has gathered texts by "la dame des Roches (perle de nostre pays Poiteuin)" and by "plusieurs doctes Aduocats et autres gentils personnages qui lors estoient à Poitiers." 9 The epistle to the reader, "Av lectevr," elides the names of both Pasquier and Des Roches, referring to her by periphrasis as "vne dame d'honneur l'vne des plus doctes \& sages que la France porte (comme ses escris peuuent tesmoigner) \& belle en perfection;" Pasquier becomes simply "[q]uelque personage assez cognu." 10 These two prefaces present the composition and the compilation of the poems in the anthology as collaborative processes of communities, showing the relationships between their members. The following discussion begins with the preface to the reader, which narrates the genesis of the volume and establishes the relationship — both actual and textual — between Des Roches and Pasquier. It then turns to the preface that precedes it, a justification of the compilation and publication of the book that frames the anthologized contest. The act of compilation itself offers a second example of group collaboration.

The preface "Av lectevr," which situates the genesis of the anthology in the conversation between Estienne Pasquier and Catherine Des Roches, is critical to an understanding of her role in the book and at the salon. The story originated with Pasquier; the preface excerpts his letter to Pierre Pithou, transforming the first person to the third person and omitting all proper names. A new first-person narrative voice - generally taken to be that of the publisher 
Abel L'Angelier - frames the account of the flea conversation with references to the published book. L'Angelier's opening refers to the expected reaction of the reader (laughter and pleasure); the closing suggests the expected response of the poets to this unauthorized publication (anger). ${ }^{11}$ This added frame to Pasquier's original flea narrative indicates the concern of the book producer to please - and tease - his audience. The section of the preface borrowed from Pasquier's letter highlights the reciprocity and cooperation that are at work on the page and at the salon. Rhetorical strategies show the ways in which Pasquier promoted Des Roches and contributed to her renown, and present a compelling argument for her equality with the puce poets.

After recounting the anecdote of the flea, the preface describes the circumstances of Pasquier's and Des Roches' first compositions. It presents a series of parallels - a doubling of images and their descriptions - that draw attention to the shared responsibility for the compositions. Reproducing the words that Pasquier ostensibly spoke to Des Roches, the text pairs images of the flea - it is "la plus prudente \& hardie que lon eut sceu desirer"- - and the reasons for writing poems in its honour-"puis que ceste Puce auoit receu tant d'heur de se repaitre du sang d'elle, \& d'estre reciproquement honorée de leurs propos." 12 The conjunction "et" distinguishes two separate attributes of the insect: it is both prudent and sure-footed; it is content to have received nourishment and honour. ${ }^{13}$ Such rhetorical doubling also draws attention to the two participants themselves; the text emphasizes their verbal sparring: "ce propos fut reietté d'vne bouche à autre par vne contention mignarde."14 The subsequent narration of the two compositions on the flea stresses the similarities in the actions of Des Roches and Pasquier:

Cette parole du commencement sembloit auoir esté proferee à coup perdu: toutesfois soigneusement recueillie des deux: Ils mirent la main à la plume en mesme temps, pensant chacun à par soy que son compaignon eut mis en oubli ou nonchaloir sa promesse: paracheuerent leur dessein en mesme heure, tombans mesmement en quelques rencontres de mots les plus segnalez, pour le subiect. Et outre ce pensans se surprendre l'vn l'autre s'entr'enuoierent ce qu'ils auoient fait. Mais en cecy furent ils eus mesmes surpris, par ce que en vn mesme instant luy ayant enuoyé d'vne main ce qui estoit de sa façon, il fut d'vne autre main salué par l'autre. ${ }^{15}$

[This initial proposal seemed to have been made for naught: but in fact it was carefully considered by both. They put their hand on the plume at the same time, both thinking to themselves that their companion had forgotten or neglected the promise; completing their work at the same time, both similarly happening to choose those words which were the most notable, for the subject. And moreover expecting to surprise one another, they simultaneously sent to the other what they had done. But in this they were themselves surprised, because in the same instant having sent to her with one hand what was his, he was on the other hand greeted by her. ${ }^{16}$ ] 
The text creates two types of movement between the poets. The repetition of "mesme" highlights their resemblance, evidenced by their simultaneous composition: "en mesme temps," "en mesme heure," "mesmement," "eus mesmes," "en vn mesme instant." To Pasquier's own suggestion that each write a poem, they react as if in unison, simultaneously writing, thinking, finishing, finding the right word, sending, surprising, and being surprised. Similarly, paired expressions - "l'vn l'autre," "d'vne main...d'vne autre main"- highlight the verbal back-and-forth, a playfulness that surprised them equally.

Borrowing Pasquier's conclusions, the preface proposes a positive interpretation of the actions of the two poets:

\footnotetext{
Heureuse certes rencontre, \& iouissance de deux espris, \& qui passe d'vn long entreget toutes ces autres opinions vulgaires de folastres d'Amour. Que si en cecy tu me permetois d'y apporter quelque chose du mien, ie veus dire de mon iugement: En l'vn tu y trouueras les discours d'vne sage fille, en l'autre les discours d'un homme qui n'est pas trop fol: aiant chascun d'eux par vne bien seance de leur sexe joué tel rolle qu'il deuoit. Or voy je te prie quel fruit nous a produit cette belle altercation, ou, pour mieux dire honneste symbolization de deux ames. ${ }^{17}$
}

[Certainly a happy encounter, and delight of two souls, and which far surpasses all those other vulgar opinions of the great follies of Love. If in this case you will permit me to bring in something of my own, I mean of my judgment: In the one you will find the words of a prudent girl, and in the other the words of a man who is not overly unreasonable; each of them having by the charm of their sex played the appropriate role. So I beg you to see what fruit was produced for us by this beautiful dispute, or, to say it better, honest affinity of two souls.]

Whereas the first paired image - "[h] announces one conclusion using two similar nouns, the expressions that follow highlight distinctions. The phrase "[e]n l'vn...en l'autre" shows their difference, reminding the reader that the resemblance between the two poets occurs within a cultural framework that insists on gender differences. Pasquier and Des Roches follow separate codes of conduct intended for men and women in order to respect the "bien seance de leur sexe." It is within the cultural context of polite society, then, that they may be considered equals. The doubling of the last sentence is presented as a rephrasing, with two expressions separated by the formulation "ou, pour mieux dire." This example characterizes the exchanges between Des Roches and Pasquier as apparent opposites: they engage in verbal battle- "belle altercation"-and they resemble one another, acting in harmony- "honneste symbolization." These seemingly contradictory expressions in fact quite aptly represent the complex 
role of women in polite society. Ann Rosalind Jones notes that the acknowledgement of gender difference more accurately characterizes Catherine's poetic responses than does the assertion of her resemblance with Pasquier. ${ }^{18}$ What interests me here is precisely this divergence between the paratext and the poems: the section of Pasquier's letter that L'Angelier excerpts centres on harmony, minimizing gender tensions to emphasize the male-female community.

The changes to Pasquier's letter - the shift to an unnamed first-person voice, the omission of proper names, the added introductory proposal to the reader of an appropriate reaction, and the concluding suggestion of the potential reaction of the poets - should be read in the context of book production and presentation. The paratext acts as publicity. The identities of the unnamed participants are not unknown to the attentive reader; the alleged fear of the publisher constitutes a ploy to tease the reader by fabricating a possible scandal. The preface "Av lectevr" elides Catherine's name, but her identity is clear: at this point in the book she has been named twice, most prominently on the title page. Likewise, the mention of the potential anger of the poets, who are reportedly not aware of this publication, should be considered an example rather of prefatory posturing by L'Angelier than of outright deception. The preface teases the reader but leaves no doubt about the identity of the "personage assez cognu" who initiated the flea contest: the following page contains five French and Latin epigrams on the flea, all attributed to Pasquier, which announce his importance to the volume. ${ }^{19}$

The prefatory paratext also draws attention to an intermediary-between the poets and the publisher - who contributed to the publication of the book. Placed before the preface to the reader, the initial dedicatory epistle, "A noble et vertvevx seignevr Ant. de la P. Gentilhomme Poicteuin," introduces the apparent compiler of the volume and explains his role. Framing the presentation of the flea contest and the resulting poems, this text reinforces the idea of community and provides the reader with a model of reception of the poems. Jacques de Sourdrai claims to have gathered the poems for publication, but he downplays this role using typical strategies of humility. Presenting his addressee as a benefactor, the author stresses his obedience to this man, whom he visited after the Grands Jours de Poitiers. The publication of the volume fulfills a promise: "Monsievr, il me souuient de la promesse que ie vous fis retournant de Poitiers"; "ie pris à commandement, la priere que vous me feistes de vous donner l'entier recueil de tout ce qui estoit venu en mes mains"; "[c]e que ie vous envoye tant pour m'acquitter de ma promesse, que pour vous tesmoigner à tousiours combien ie desire demeurer prest à receuoir vos commandemens. ${ }^{20}$ The compiler presents his function as second- 
ary, using expected formulas of inadequacy to argue that his contribution is minimal. The expression "tout ce qui estoit venu en mes mains" implies that Sourdrai secured possession of the poems by chance rather than premeditated action. The statement that he has not been able to gather all of the poems - "il ne m'a esté possible de pouuoir amasser toutes les richesses" 21 - conveys humility, but it also entices the reader with the suggestion that additional texts remain unpublished. ${ }^{22}$ Finally, by noting that readers can themselves participate in the compilation of poems - "Chacun y pourra apporter ce qu'il aura peu retirer de son costé" 23 - Sourdrai brings the reader into the collaborative venture of book-making.

The process of "making public" these poems, which leads to their publication, also engages the company gathered at the home of Sourdrai's benefactor. In its composition and conversation, this group resembles the participants in the Des Roches salon; Sourdrai refers to the "doctes \& gentils discours de l'honneste \& noble compagnie que vous auiez chez vous." 24 One topic of conversation was the Poitiers Grands Jours; the preface presents the salon gatherings as an agreeable retreat from the judicial proceedings. Sourdrai dichotomizes the pursuits of the two locations in a sentence that skips back and forth between periphrastic expressions that refer to each:

Il me souuient qu'entre autres choses il fut fort parlé des grands Iours de Poitiers, tant pour la bonne iustice \& expedition qui s'y estoit faicte, que pour la gentillesse de plusieurs braues esprits et grands personnages qui y estoient, lesquels retirez de leur plus graue estude daignoient bien toucher le luth d'Apollon, \& laisser là Bartolle \& les sacs pour quelque heure, se rafreschissans par le moyen d'un plus agreable $\&$ doux labeur, quel est celuy de la Muse. ${ }^{25}$

[I remember that among other things the Grands Jours de Poitiers were much discussed, as much for the good justice that was dispatched there, as for the distinction of several noble wits and important persons who were there, who, withdrawing from their more serious study deigned to touch Apollo's lute, and to leave behind Bartolo and their dossiers for several hours, refreshing themselves with a more agreeable and pleasant labour, which is that of the Muse.]

This description designates the jurists' official business as "bonne iustice \& expedition," "leur plus graue estude," and "Bartolle \& les sacs," whereas the salon offered "un plus agreable \& doux labeur, quel est celuy de la Muse," a place for "la gentillesse de plusieurs braues esprits et grands personnages" to "toucher le luth d'Apollon." The verbs - "retirer," "laisser," "se rafraichir"distinguish the two places by noting the physical separation of those jurists who frequented the salon; the distinction emphasizes the seriousness of the court activities. Sourdrai draws a telling parallel between that situation and 
his own: just as the Grands Jours magistrates found welcome relief in their poetic compositions, he took pleasure in compiling those verses as a respite from his own current legal wrangling over landholdings:

\begin{abstract}
Or d'autant qu'alors \& pardeuant Messieurs des grans Iours ie poursuyuois le iugement du procez que i'auois contre plusieurs legataires pour la terre de la Ronciere, à fin de donner à mon esprit quelque relasche, Je pris plaisir à recueillir le plus fidelement qu'il me fut possible plusieurs gentilles \& doctes inuentions en vers, tant de la Dame des Roches (perle de nostre pays Poiteuin) que de plusieurs doctes Aduocats et autres gentils personnages qui lors estoient à Poitiers. ${ }^{26}$
\end{abstract}

[So because then and before the magistrates of the Grands Jours, I was pursuing the verdict in the case that I had against several legatees for the property of la Roncière, so as to give some rest to my mind, I took pleasure in collecting as faithfully as possible several worthy and learned inventions in verse, by the Dame des Roches (pearl of our Poitevin land) as well as by several learned Lawyers and other excellent persons who were then in Poitiers.]

The expression "alors \& pardeuant" situates Sourdrai's own legal case as simultaneous with the Grands Jours. Similarly, the effect of his collection of the poems is analogous to the repose the jurists found in the poetry and conversation of the salon.

An extension of the parallel between the Des Roches salon and the company gathered around Sourdrai's addressee introduces an appropriate model for reading the poems in La Puce. The preface depicts this group's desire to hear the flea poems and their reaction: "Vous me priastes d'en reciter quelque chose,...ce que ie fis tres volontiers. En quoy vous pristes tel goust, ensemble plusieurs Gentilshommes, \& entre autres quelques sages \& belles Damoiselles...."27 The fact that this group includes men and women indicates that the book is appropriate for both sexes. The preface frames the narration of the puce conversation and composition with this community, which prefigures the community of two-Des Roches and Pasquier-in the preface that follows.

The prefatory texts in La Puce designate the book that will follow as an example of group production. The poems themselves express collective authorship by highlighting individual points of view. Many belong to the genre of the pièce responsive. ${ }^{28}$ Whereas the poets occasionally confirm one another, they most often contradict or correct, addressing one another directly: "Mignarde, vous auez grand tort"; "Il ne faut, Pasqvier"; "Ne croy pas, mon Binet." 29 This is most evident in the male-authored blasons that detail the female body, and in Catherine Des Roches' careful replies. The paratextual materials, on the other hand, downplay the bawdy aspects of the flea contest 
and the resulting poems. They emphasize the group endeavor as a process of collaboration, exemplified by the combined efforts of the puce poets, the compiler Jacques de Sourdrai, and the publisher Abel L'Angelier, as well as by the resemblance of Des Roches and Pasquier.

The affinity-"symbolization"- between the two originators of the flea contest recalls another pair of writers, Catherine and her mother Madeleine Des Roches. In the paratexts of the Des Roches' three published collections, these writers use different strategies to present their works. ${ }^{30}$ The Des Roches divide each of their volumes of poetry and prose-Les Oeuvres (1578-1579), Les Secondes oeuvres (1583), Les Missives (1586) - into two sections, the mother's works preceding the daughter's. ${ }^{31}$ Their liminary epistles contain mutual address, dedication, and praise, inscribing the familial bond. The women isolate themselves in this community of two in an act of literary self-promotion. Despite the differences between the joint publications of the mother and daughter and that of the salon, the paratexts of both bodies of work reveal exemplary early modern communities - communities that produce texts. To focus on the paratext of books produced by the Des Roches' circle - whether narrowly or broadly defined - is to direct attention to the collaborations of literary communities in sixteenth-century France.

Wake Forest University

\section{Notes}

1. On the salon as a space of collaboration and competition, see Ann Rosalind Jones, "Contentious Readings: Urban Humanism and Gender Difference in La Puce de Madame DesRoches (1582)," Renaissance Quarterly 48 (1995), pp. 109-28; and Anne R. Larsen, "On Reading La Puce de Madame Des-Roches: Catherine des Roches' Responces (1583)," Renaissance and Reformation / Renaissance et Réforme 22: 2 (1998), pp. 63-75.

2. Madeleine and Catherine Des Roches, Les Oeuvres (Paris: Abel L'Angelier, 1578) ed. Anne R. Larsen (Geneva: Droz, 1993).

3. La Puce de Madame des-Roches (Paris: Abel L'Angelier, 1582). Jones reads the volume as a "group performance" ("Contentious Readings," p. 127).

4. Gérard Genette, Seuils (Paris: Seuil, 1987), p. 8.

5. Cynthia J. Brown, Poets, Patrons, and Printers: Crisis of Authority in Late Medieval France (Ithaca and London: Cornell University Press, 1995). See also Leah Chang's study of the negotiations between women writers and their book producers in sixteenth and early seventeenth-century France, in "Printing the Muse: Book Production and the Construction of Female Authorship in Renaissance France" (PhD dissertation, University of Michigan, 2002).

6. Brown, p. 10.

7. See Jones; also, Todd P. Olson, “'La Femme à la Puce et la Puce à l'Oreille': Catherine Des Roches and the Poetics of Sexual Resistance in Sixteenth-Century French Poetry," 
Journal of Medieval and Early Modern Studies 32 (2002), pp. 327-42; and Cathy Yandell, "Of Lice and Women: Rhetoric and Gender in 'La Puce de Madame des Roches'," Journal of Medieval and Renaissance Studies 20 (1990), pp. 123-35. Anne Larsen analyzes Catherine Des Roches' use of the genre responsif in La Puce and investigates the reasons for her republication of these poems in Les Secondes oeuvres in 1583 ("On Reading La Puce de Madame Des-Roches").

8. Jones notes the ambiguity of the title, which may refer to the woman as the body hosting the flea or as the poet who initiated the collection ("Contentious Readings," p. 126).

9. La Puce de Madame des-Roches, fol. a-ii ${ }^{\mathrm{r}}$.

10. La Puce, fol. a-iii ${ }^{\mathrm{r}}$.

11. On L'Angelier's publication of La Puce de Madame des-Roches, see Jean Balsamo, “Abel L'Angelier et ses dames: Les Dames des Roches, Madeleine de L'Aubespine, Marie Le Gendre, Marie de Gournay," Des femmes et des livres: France et Espagne, XIV $V^{e}$ XVII siècle, ed. Dominique de Courcelles and Carmen Val Julien (Paris: École des Chartes, 1999), pp. 117-39.

12. La Puce, fol. a-iiir .

13. The opening of Pasquier's letter, which the preface does not excerpt, opens with a doubling that highlights the different roles Catherine Des Roches plays. A series of double images - two people, two things, two attributes of a person or thing - centres on Catherine Des Roches, drawing attention to the fact that she acts in conjunction with someone else. Noting the circumstances of his first visit to the Des Roches family and his initial impressions of the mother and daughter, Pasquier first presents two pairs of people_- "Monsieur Loysel et moy" and the Dames Des Roches, "mere et fille"-followed by two attributes of the women- "honneurs vrayement, et de la ville de Poitiers, et de nostre siecle" (Les Lettres [Paris: Abel l'Angelier, 1586] fol. 186 ${ }^{\mathrm{V}}$ ). This type of doubling of Madeleine and Catherine Des Roches was typical in contemporary references, including the title pages of their published works.

14. La Puce, fol. a-iiir ${ }^{\mathrm{r}}$.

15. La Puce, fol. a-iiir .

16. All translations are mine.

17. La Puce, fol. a-iiir ${ }^{\mathrm{r}-\mathrm{v}}$.

18. Jones, pp. 121-22.

19. In his closing "A. l'Angelier aux Lecteurs," the publisher notes again that he has printed the book in secret_- "comme à la desrobee" — and confirms Pasquier's displeasure, which he had anticipated in the preface: "Comme de faict celuy qui descouurit le premier ce tant renommé animal \& qui premier mit en train tant de doctes personnages sur ce suiect, estant aduerti qui i'imprimois ceste Puce ne vouloit consentir que i'acheuasse" (La Puce, fol. $94^{\mathrm{V}}$ ). Jean Balsamo links this enticement of the reader to the potential benefits of producing this volume, which L'Angelier clearly recognized (“Abel L'Angelier et ses dames," p. 125).

20. La Puce, fol. a-ii ${ }^{\mathrm{r}}-\mathrm{a}-\mathrm{ii}^{\mathrm{V}}$.

21. La Puce, fol. a-ii . 
22. The hint that a future publication may include even more poems is made explicit in the preface to the second section of the anthology, which uses Sourdrai's anagram- "QVI A VOVS SE DEDIRA"- and so appears to be written in his voice. This preface "Avx lectevrs" mentions that some poems have been withheld selfishly, and the speaker vows to print them if possible (La Puce, fol. $60^{\mathrm{V}}$ ).

23. La Puce, fol. a-ii ${ }^{\mathrm{V}}$.

24. La Puce, fol. a-iir .

25. La Puce, fol. a-iir .

26. La Puce, fol. a-ii ${ }^{\mathrm{r}}$.

27. La Puce, fol. a-ii ${ }^{\mathrm{r}-\mathrm{v}}$.

28. On the responce, see Larsen, "On Reading La Puce de Madame Des-Roches"; Joyce Miller, "In the Margins of Amatory Discourse: The Responces of Pernette du Guillet," Sixteenth Century Journal 24 (1993), pp. 351-68; and Howard H. Kawlies, "The Responce Genre in Early French Renaissance Poetry," Bibliothèque d'Humanisme et Renaissance 65 (1983), pp. 77-86.

29. La Puce, fol. $22^{\mathrm{V}}$; fol. $27^{\mathrm{V}}$; fol. $29^{\mathrm{r}}$.

30. Kirk D. Read argues that the bond that the mother and daughter express in the liminary epistles constitutes a female community ("Women of the French Renaissance in Search of Literary Community: A Prolegomenon to Early Modern Women's Participation in Letters," Romance Languages Annual 5 [1993], pp. 95-102).

31. Les secondes oeuvres, ed. Anne R. Larsen (Geneva: Droz, 1998); Les Missives (Geneva: Droz , 1999). 